\title{
Hva er problemet?
}

Som fersk turnuskandidat ved Hammerfest sykehus mottok jeg et lite, rødt hefte på 32 sider i posten. Heftet var merket «YLF» og viste seg å være den aller første utgaven av et medlemsblad for Yngre legers forening. Redaktøren het Knut Eldjarn og året var 1986. Jeg leste ikke heftet særlig nøye der og da. Jeg var oppslukt og overveldet av turnustjenesten og hadde mer enn nok med den bratte læringskurven. Det var langt fra auditoriet på Rikshospitalet til akuttmottaket og sengepostene ved Hammerfest sykehus på mer enn én måte.

I løpet av året utkom til sammen fire numre av bladet, som ved slutten av året hadde fått navnet Ylf-forum. Høsten 1986 hadde jeg noe mer tid til og interesse av å lese bladene jeg hadde mottatt. Jeg hadde, til arbeidsgiverens og det daværende turnuskontoret i Oslos forargelse, fått mitt barn nummer to i sommerferien mellom indremedisinsk og kirurgisk turnustjeneste. Det var ikke i tråd med verken tjenesteplanene eller langtidsplanen for utplassering av turnuskandidater. Jeg skjønte da - og enda bedre siden - at både godkjenning av turnustjenesten og videre karriere kunne blitt atskillig vanskeligere hvis ikke Ylfs tillitsvalgte på sykehuset hadde bistått.

Ylf-forum nr. 4 kom i postkassen rett oppunder jul 1986 og var spesielt interessant. Det markerte Ylfs 75-årsjubileum og inneholdt tilbakeblikk og analyser av problemstillinger jeg verken hadde lært om eller reflektert over i studietiden: At det langt fra var noen selvfølge at offentlige myndigheter, arbeidsgivere og overordnede var interessert i gode vilkår for videre- og etterutdanning av legene. Det var snarere som oftest en motsetning mellom behovet for nødvendig kompetanseutvikling hos den enkelte og ønsket om bl.a. billigere og mer effektiv drift av sykehusene. Jeg hadde tenkt (sikkert naivt) at høyt kvalifiserte leger og annet helsepersonell var i alles og særlig helsemyndighetenes - interesse, fordi det økte kvaliteten på helsetjenesten som helhet. Nå fikk jeg øynene opp for at de ordninger og rettigheter som ville gjøre det praktisk og faktisk mulig for meg å videreutdanne meg som lege og gjøre en tilfredsstillende jobb, ikke var kommet på plass etter påtrykk fra arbeidsgivere, helsemyndigheter eller f.eks. de medisinske fakultetene, men gjennom beinharde forhandlinger i en årrekke og strenge kollegiale bestemmelser som forpliktet og bandt legene på ulike vis. Jeg begynte også - iallfall vagt - å forstå at sentrale helsemyndigheters gjennomføring av lover og forskrifter som fratok legene selvbestemmelse, ville kunne få betydning for det kollegiale ansvaret legene følte for å bidra til en best mulig helsetjeneste.

«Det må arbeides for å sikre en bedre spesialistutdanning. Som følge av avtaleforslaget må det stilles nye og strenge krav til myndighetene og sykehuseiernes innsats for utdanningen av legespesialister. Siden det ikke lenger vil være et kollegialt ansvar å utdanne spesialister, må det sikres midler og tid på legenes tjenesteplaner til klinisk utdanning og veiledning.» Lyder det kjent? Det ble skrevet av Knut Eldjarn i den første utgaven av Ylfs medlemsblad (1). En rekke av de andre artiklene i den første årgangen står seg godt ved gjennomlesing nesten 25 år senere. Det gjelder ikke minst daværende Ylf-formann Albert Paus' refleksjoner over betydningen av den nylig innførte arbeidsmiljøloven (1977) og effektivitetskravene i sykehusene for kontinuiteten i lege-pasient-forholdet og kvaliteten i spesialistutdanningen (2). Men også en rekke tidligere formenn i Ylf ga viktige bidrag til å forstå hvilke interesser som har stått mot hverandre - og på spill (3). Ingen enkelt gruppe eller organisasjon hadde hatt monopol på makt og virkemidler. Legeforeningen er ikke én, men flere foreninger, med til dels helt motstridende interesser. Helsemyndigheter, arbeidsgivere og universiteter har heller ikke alltid sammenfallende mål og preferanser. Dette er viktige forutsetninger for at organiseringen av spesialistutdanningen er blitt slik den er i dag $(4,5)$. Det er en nyttig bakgrunn for refleksjon når helseministeren nå ønsker «å ta grep» for å endre og forenkle.

I Dagbladet 15. februar 2009 rettet tidligere stortingsrepresentant Paul Chaffey kraftig kritikk mot norsk helsevesen (6). Som far til en multihandikappet sønn på 12 år har han både høstet erfaringer og gjort seg sine tanker. Han var varsom med å trekke for generelle konklusjoner fra sin personlige erfaring, men hadde refleksjoner som mange vil kjenne seg igjen i - enten vi har vært pasienter, pårørende eller samarbeidspartnere. Han mente at norske sykehus «står seg godt rent medisinsk», men at et stadig voksende byråkrati, for lite samarbeid, dårlig logistikk og manglende kommunikasjon skapte problemer, irritasjon og angst. «Man bør helst bare ha én lidelse av gangen, fordi spesialistene befinner seg i to eller flere avdelinger som ikke er særlig gode til å snakke sammen.» Sagt på en annen måte: Hovedproblemet i dagens helsevesen er ikke kvaliteten på den enkelte lege eller spesialist, men at spesialistene (og andre) ikke kommuniserer godt og kanskje heller ikke respekterer hverandre. Ansvaret for å endre på dette organisatorisk og holdningsmessig påligger både den enkelte lege, Legeforeningen og selvsagt de ansvarlige myndigheter. Det haster med å få løst denne utfordringen.

«Hva er problemet, og hvem har problemet?» pleide en av assistentlegene på kirurgisk avdeling i Hammerfest brutalt å avbryte meg med når jeg viklet meg inn i lange, snirklete resonnementer - $\mathrm{i}$ god akademisk tradisjon - etter å ha tatt opp journal. Assistentlegen, Steinar Solberg, ble for øvrig senere leder både av Ylf og av Tidsskriftets redaksjonskomité. Spørsmålene kan med rette stilles også i den pågående debatten om organiseringen av legenes videre- og etterutdanning. «If it ain’t broke, don't fix it», lyder et amerikansk ordspråk.

\footnotetext{
Charlotte Haug

Redaktør

Litteratur

. Eldjarn K. (redaksjonelt). Ylf 1986; Nr. 1:3

Paus A. Formannen har ordet. Ylf-forum 1986: nr. 4: 7-23.

Eldjarn K. Glimt fra Ylfs historie. Ylf-forum 1986; nr. 4: 7-23.

. Janbu T. God spesialistutdanning - god helsetjeneste. Tidsskr Nor Legeforen 2009; 129: 443

5. Haug C. Akuttbehandling av spesialistutdanningen. Tidsskr Nor Legeforen 2009; 129: 279.

6. Ringheim G. Etterlyser politisk mot. Dagbladet 15.2.2009.
} 